\title{
ERRORS IN USING ENGLISH AS CLASSROOM LANGUAGE COMMITTED BY THE ICT TEACHER OF SMP NEGERI 2 SEMARANG
}

\author{
Huyi Intan Sari \\ Semarang State University \\ huyiintansari@yahoo.com
}

\begin{abstract}
This article aims to discuss the problems faced by the ICT teacher of SMP Negeri 2 Semarang in using English as classroom language. The International Standard School project is a new education policy in Indonesia that was enacted with a main goal to prepare the students for global competition. This policy is both an effort to internationalize schools in Indonesia and a part of the national education decentralization reform. The title International Standard School, SBI in Bahasa, is given as an accreditation status to schools that have completed the required standards. This accredited status requires the school to carry out teaching and learning process all in English. This applies to all subjects including ICT. This article is based on the observation on the teaching and learning process in ICT class at SMP Negeri 2 Semarang as one of famous International Standard Schools in Semarang. The observation has resulted in general problems which is elaborated in the teaching documents four aspects of language mastery; fluency, pronunciation, grammar, and vocabulary.
\end{abstract}

Keywords: ICT teachers, International Standard School, errors in using English as classroom language

\section{INTRODUCTION}

Based on the law No. 20 year 2003 about the National Education System (SISDIKNAS), the government has an obligation to set up at least one International Standard School (SBI) in each level of education in each city or region. One of the requirements for teachers in International Standard Schools is the English mastery. According to Directorate General of Dikdasmen (1997), teachers of SBI are supposed to be able to communicate in English (to read English books and references, to write learning materials, papers, modules in English, and to teach the subject matters in English). The teachers must have TOIEC score of at least 550. So it has become unavoidable demand that teachers of SBI need to be able to teach in English. 
Journal of English Education, Literature, and Culture

Realizing the need to equip their teachers with English mastery, all International Standard Schools oblige their teachers to take English courses. At the beginning, the schools ask lecturers of English Department of a university to set up English for Specific Purposes (ESP) program in teaching. The program usually includes basic grammar, common expressions in English classrooms (how to open and end a lesson, how to ask questions, how to give orders etc), and simple English texts related to teaching materials. Some schools also send their teachers to professional English courses for several months. The teachers are also taught how to write lesson plans in English. When the initial program has finished, the teachers are provided with micro teaching programs in which they must practice conducting the teaching and learning process in English. The schools pay all the course expenses and the needed books. Some schools even provide some amount of allowance money to motivate the teachers.

Not all teachers, however, participate whole-heartedly in the process of preparing them to be able to teach in English. Very few teachers take the English courses seriously. Some teachers say that English is too difficult for them and they do not have enough time to study English. Some others say that they are afraid the students will not understand the lesson if it is delivered in English. Then, it is not surprising that the English mastery of teachers of International Standard Schools is very poor. Surya Dharma, MPA, Ph D (Kompas, 2009) said that based on TOEIC, it is revealed that the English mastery of teachers and principals of International Standard Schools is generally poor, 60 percent of them have the lowest level of English mastery.

The poor English mastery is found in teachers of all non English subjects, including teachers of Information and Communication Technology (ICT). It is a little bit surprising because ICT materials use a lot of English terms or jargons that are not yet translated in Indonesian, like enter, screen, keypad, value and many others. It means that ICT teachers saw, read and dealt with a lot of English when they were studying the subject in universities since almost all ICT materials are written in English. Moreover, ICT teachers are generally young because ICT is a new subject in schools so they generally have higher motivation in studying English than teachers of other subjects that are generally older. The ICT teachers are aware of the importance of English mastery as the current development in ICT field is mostly written in English. 
Journal of English Education, Literature, and Culture

This article aims at finding the problems that the ICT teacher of SMP Negeri 2 Semarang faces when delivering the lesson in English despite the fact that the teacher concerned did not take English as her major for S1 study and the awareness that she has over the importance of English mastery to keep up with the latest development in ICT field.

Policy for Setting up International Standard Schools

In order to improve the quality of education, the government, through the Ministry of Education, has made a lot of programs. One of the programs is setting up International Standard Schools. An International Standard School is defined as a school which has achieved and done all of the eight national standards of education, namely the standards of content, process, graduate's competence, educators and administration staff, structure and infrastructure, management, finance, and evaluation. The eight standards are then enriched, deepened, strengthened, and developed by adapting or adopting the education standards of one developed country whose educational quality is widely acknowledged. International Standard Schools are expected to give quality assurance in the process of teaching and learning and better results.

International Standard Schools are based on existentialism and essentialism philosophy. Existentialism believes that education must grow and develop the existence of students as much as possible by developing their intellectual, emotional and spiritual ability. Essentialism philosophy emphasizes that education be functional and relevant with the needs of the students and society. Education must prepare Indonesian human resources to be able to compete in this global era.

Up to now the majority of International Standard Schools are in the phase of preparation. In the phase, there are two stages that need to be done; the first is the development of the human resources, the management and institute modernization, and the second is consolidation. 
Profile of International Standard Schools

\begin{tabular}{|c|c|}
\hline Parameter & Requirements \\
\hline $\begin{array}{l}\text { National Education } \\
\text { Standards }\end{array}$ & Have all been accomplished \\
\hline Teachers & $\begin{array}{l}\text { Min S2/S3: 10\% (Elementary School), 20\% (Junior High School), } \\
\text { 30\% (Senior High School) }\end{array}$ \\
\hline Principal & Min S2 and able to communicate in English \\
\hline Accreditation & A (95) \\
\hline $\begin{array}{l}\text { Structure and } \\
\text { infrastructure }\end{array}$ & ICT base \\
\hline Curriculum & $\begin{array}{l}\text { School based curriculum enriched with the curriculum from the } \\
\text { curriculum from an advanced country, the implementation of } \\
\text { credit system in senior high schools }\end{array}$ \\
\hline Learning Process & $\begin{array}{l}\text { ICT based, bilingual, sister school with a school from an } \\
\text { advanced country }\end{array}$ \\
\hline Management & ICT based; ISO 9001 and ISO 14000 \\
\hline Evaluation & Implementing Final Exam (UN) and International exam \\
\hline Graduate & Possessing international competence to pursue further education \\
\hline School Culture & $\begin{array}{l}\text { Character education, free from Bullying, Democratic, } \\
\text { Participative }\end{array}$ \\
\hline Finance & $\begin{array}{l}\text { APBN, APBD and are allowed to collect money from the } \\
\text { society based on accountable RAPBS ; min } 20 \% \text { students } \\
\text { from poor family are subsidized }\end{array}$ \\
\hline
\end{tabular}

Teachers' Profiles of International Standard Schools

The Law of Teachers and Lecturers states that:

- A teacher must have academic qualification and competence of a learning agent.

- A teacher is said to have academic qualification if he/she holds a bachelor degree in a field which is in accordance with the subject that he/she teaches.

- Teachers' competence includes pedagogical competence, personality competence, professional competence and social competence.

Pedagogical competence is the ability to manage the students' learning which includes teachers' understanding about the students, planning and 
Journal of English Education, Literature, and Culture

implementing learning activities, evaluation, and the development of students to actualize all of their potentials.

In personality competence, teachers are expected to be wise, mature, charming and have good personality. Social competence is the teachers' ability in communicating and interacting effectively with students, fellow teachers, administration staff, parents and society.

Professional competence is the teachers' ability in mastering subject matters deeply and widely which enable them to facilitate the students to get the required competence. According to the manual of International Standard Schools, teachers of International Standard Schools must:

1. have $\mathrm{S} 1$ or $\mathrm{D} 4$ degree

2. have the competence to carry out his or her job or functions

3. be able to communicate in English (to read English books and references, to write learning materials, papers, modules in English, and to teach the subject matters in English). The teachers must have TOIEC score of at least 550.

4. be able to operate computers (have the ability to use ICT as a teaching aid, have the ability to produce teaching materials using one or more electronic media, have the ability to download and upload teaching materials using internet.

\section{ICT Teaching}

Information Communication Technology (ICT) is a constantly developing subject within society and the National Curriculum (NC). Areas within ICT are vital to our everyday lives, and sometimes we forget that we live in an information age. By understanding and been able to use the tools that ICT provides, we are better able to solve problems and to work more efficiently. ICT more specifically inside the classroom has developed immensely. Technology has become a part of our culture therefore it is very important that we are educated in how to use it, not only for the classroom but also for the workplace. Studies have shown that ICT is a popular subject among students.

The effect of ICT on all subject areas affected the curriculum, society and also interest levels of the vast majority of students. As ICT became a vital part of society the way it is taught has also changed due to the advances in technology and resources. ICT has now become a part of our culture that can be learnt 
Journal of English Education, Literature, and Culture

both practically and theoretically. ICT skills where demonstrated not only theoretically through exams and written assignments, but also through coursework's and practical assessments.

ICT educators, whilst specializing in the field themselves, aim to teach the implementation of computers and computing technology in order to achieve effective processing information. An ICT teacher should teach students so that they acquire the ability to make use of software tools for problem solving requires the acquisition of a number of ICT skills, e.g. remembering commandos and dialogue boxes, finding details associated with the software, understanding the software functions and their relationships, understanding the overall principles of the software, finding the right sequence, creating associations in their own language, transferring previously acquired skills to the software, etc.

According to Herskin (2004), teaching these skills involves two major steps. First, the teacher gives an overview and demonstrates the functionality of the software. Second, the students do hands-on exercises using the software. During the overview the teacher uses a video projector to present the software functions, and demonstrates how the following exercise should be solved. Then, the students work on their own, trying to remember this procedure. There are three basic problems that are related to this form of teaching ICT:

1) The memory problem: The student must remember a detailed procedure.

2) The understanding problem: The student has not understood the principles of how to solve the exercise.

3) The dependence problem: The student is not able to work on his own solving the problem.

Techniques, such as teaching small groups, breaking down the lessons into smaller parts, providing the students with detailed manuals showing how the exercise should be solved step-by-step, using textbooks, or adopting similar methods, do not solve the basic problems of traditional ICT teaching. However, it is important for teachers not be overwhelmed by trying to master all the details of software but to focus on the main features of types of software and how to find information about the detailed techniques. In line with this approach, Herskin (2004) proposes a teaching method relying on ICT pedagogical principles with three objectives: 
Journal of English Education, Literature, and Culture

1) First, an important objective is to remove the details needed to be remembered, using a problem-oriented understanding process, and changing the focus from memorizing to understanding. For this purpose, the concept of instruction sheet is proposed.

2) Second, for generating understanding, teachers use "understanding tools".

3) Third, a pedagogical strategy is identified consisting of the single steps of the learning process, and the problems associated with them.

As a result, the pedagogical strategy for teaching ICT has three majors, but closely related phases:

a) Overview phase (or presentation phase) of which the objective is to generate understanding using "understanding tools".

b) Exercise phase (or hands-on phase) gives students situated examples, visualizing, and dialogues. By using situated examples, the teacher should be enable the students to understand the problem. The principles are then explained through visualizing.

c) Summary phase. Finally, the teacher gives a procedure overview using visual boxes showing the main steps of the problem solving process.

\section{English as Classroom Language}

English as classroom language refers to one that uses English as the primary medium of instruction. A medium of instruction is the language used in teaching. The interaction between teachers and students during the teaching and learning process is all done in English. Consequently, knowledge of English plays the most important part in the success of the teaching from the side of both the teacher and the students.

Transmitting an education program through a foreign could be difficult when the teachers themselves do not speak the language (English) fluently. As regulated by the government that an accredited International Standard School should carry out the teaching and learning process all in English including in the teaching manuals and documents, the use of English as a classroom language is becoming unavoidable despite the problems the non-English teachers most probably face in carrying out such an obligation. 
Journal of English Education, Literature, and Culture

It is hence assumed that teachers in an International Standard School have to do two things at once: first, they have to learn the subject-matter knowledge in English and at the same time they have to acquire the ability to use English as the medium of instruction in delivering the knowledge of the subject to the students during the teaching and learning process.

According to Clegg (2003), if teachers want to teach their students a subject in English, when they are not fluent in that language, subject teachers are the ones who have to shoulder much of the burden of the students' language development rather than the language teachers. This issue, however, is overlooked by many parties that are responsible in developing and implementing this curriculum change. Kennedy (1997) states that prior beliefs held by teachers hinder their learning about teaching. The policy makers and administrators have to take into account the importance of the teachers' dispositions that contributed to the confidence and self-perceived competence in using English to teach the subject as well as the motivation for achievement.

Moreover, the use of English as classroom language is realized during the interaction process between teachers and students in stages of opening, introduction of the material, presentation of material, exercises, evaluation and reflection. To encourage students to speak only in English in the classroom, teachers will have to make sure they know simple transactional phrases that they can use to manage their interaction. Often these phrases come so naturally in the native language that it is difficult to break the habit.

Here are some phrases efficient to be used during the teaching and learning process.

Classroom Language: The beginning of the lesson

\section{Greeting}

- Good morning, everybody.

- Good afternoon, everybody.

- Hello, everyone.

- Hello there, James.

- How are you today?

- How are you getting on?

- How's life?

- How are things with you?

- Are you feeling better today, Bill? 
Introductions

- My name is Mr/Mrs/Ms Kim. I'm your new ICT teacher.

- I'll be teaching you English this year.

- I've got five lessons with you each week.

Time to begin

- Let's begin our lesson now.

- Is everybody ready to start?

- I hope you are all ready for your English lesson.

- I think we can start now.

- Now we can get down to work.

Waiting to start

- I'm waiting for you to be quiet.

- We won't start until everyone is quiet.

- Stop talking and be quiet.

- Settle down now so we can start.

\section{Register}

- Who is absent today?

- Who isn't here today?

- What's the matter with Linda today?

- What's wrong with Jim today?

- Why were you absent last Friday, Linda?

Classroom language: Classroom management

- Make groups of four.

- Move your desks into groups of four people.

- Turn your desks around.

- Make a horseshoe shape with your desks.

- Make a circle with your desks.

- Make a line of desks facing each other.

- Make groups of four desks facing each other.

- Sit back to back.

- Work together with your friend.

- Find a partner.

- Work in pairs/threes/fours/fives.

- Work in groups of two/three/four.

- I want you to form groups.

- Form groups of three.

- Here are some tasks for you to work on in groups of four.

- Everybody work individually.

- Work by yourselves.

- Work independently.

- Ask your neighbor for help.

- Work on the task together.

- Have you finished?

- Do the next activity. 
- Move on to the next activity.

Problems in Using English as Classroom Language Faced by the ICT Teacher of SMP Negeri 2 Semarang as An International Standard School

- As an International Standard School, it is required that all the teaching learning processes are done in English as an International classroom language. Therefore, it is a must that teachers carry out his/her teaching in English. This is what makes the observation more interesting since we would see how the ICT teachers whose major was not English had to deliver their teaching all in English.

- It is clearly seen that language competence is the point where nonEnglish subject teachers are inevitably handicapped. However, one cannot generalize that all such teachers are deficient users of English. They may have some gaps in using English as their teaching medium. There are some patterns in the areas of difficulties. The most frequent areas are: fluency and vocabulary, followed by speaking, pronunciation, and listening comprehension. At the bottom of the list were grammar, idiomatic expressions, appropriacy, intonation, and prepositions.

(1) Vocabulary: There are some problems with the English lexicon as well as with any other language: many words have different meanings according to the context, idioms, synonyms, etc. In short, vocabulary resists mastery.

(2) Fluency: Oral fluency requires many qualities, such as readiness to speak, speech rate, etc, in which non-English subject teachers are in a disadvantage. Their speech tends to be redundant and clumsy due to the difficulty in finding the right structures at the right time.

(3) Pronunciation: It is obvious that non-English teachers are marked by a foreign accent that in the worst cases interferes with other people's understanding.

(4) Grammar: Grammar is the favorite field for non-English teachers. It is said to be more concrete and more learnable than vocabulary. The teacher is good enough to design the syllabus in English. This is a good start for the nonEnglish teacher to prepare his/her syllabus in English as it will force his/her to be able in using English in written form. Hence, this will also encourage him/her to use spoken English during her teaching. 
Moreover, the observation that has been done at SMP Negeri 2 Semarang has resulted in the diagnosis of problems faced by ICT teachers occurring during the teaching and learning process which was carried out with the use of English as a teaching medium. The observation was intended to see how the problems take place during the interaction between the teachers and the students and how the teachers cope with all those problems. One main reason why it was the ICT class of an International Standard School (SBI) being observed is because it is interesting to see how the non-English teacher designs all the teaching documents in English and how she delivers the teaching and learning process also in English. These two aspects are somehow interesting considering the fact that the teacher concerned did not take English as her major for her S1 study.

SMP Negeri 2 Semarang was chosen as the school is one of famous SBI schools in Semarang with a high reputation for its achievement in academic competition. Grade VII class was picked out as the most representative class to be observed since it is quite easy to have all students cooperated in the activity. The observation on the teaching and learning process was done on June, 4. The teaching and learning process was carried out on class VIIG, with 24 students. The class was discussing MS. Access at second up to third period of time.

The result of the observation is elaborated in two parts; some problems found during the teaching and learning process and some findings in teaching documents overview as an additional supplement to this article.

\section{FINDINGS IN THE OBSERVATION ON TEACHING AND LEARNING PROCESS}

ICT subject is taught once a week in a period of 80 minutes. The lesson takes place in a computer laboratory where there is one computer for each student. The room is equipped with an LCD projector and an internet connection. During the teaching and learning process, the teacher definitely used English as her medium of teaching although there were several unavoidable mistakes taking place. Following is the result of the observation 
Journal of English Education, Literature, and Culture

dealing with teacher's incapability in using English as her language for communicating with her students.

1) Vocabulary

Lack of English vocabulary resulted in the repetition of some words. For example: the teacher happened to use the same word 'task' instead of 'work'. She produced the same utterance "Let's do the task" several times instead of saying "Work on the activity number 1". She also used the word identify" repeatedly when saying "Identify the menu and icon!' instead of saying "Show me which one is the menu!"

\section{2) Fluency}

Redundant and clumsy fluency occurred as the teacher sometimes did not know how to use a certain expression in English and produced long sentences which were meaningless. For example; "Click on each and every button on icon", "Repeat again click menu", "Return again in menu", and etc.

3) Pronunciation

Some words happened to be mispronounced by the teacher. For example; icon was pronounced /aikon/, menu /menu/, homework / homework/, data /data/, and etc.

4) Grammar

The teacher often made grammatical errors when using some expression, such as "Are you understand?", "I will going to explain on Ms. Access today", "Make listing the menu and icon", and "Make groups to discussing the menu".

\section{Some Other Facts Found in the Observation}

1. The teacher was good enough in presenting the material in English. The teacher has bravery to speak up in English. It's good start for non English teacher to teach in English, because she will get used to using English in instructional process.

2. The teacher is able to design the syllabus well enough. 
Journal of English Education, Literature, and Culture

3. It is a good start for the non English teacher to prepare his/ her syllabus in English, so he/ she will be get used to using English in learning teaching activity.

4. The learning activity has reflected what he/ she prepared before, although there are still some mistakes in stating the terms.

5. The teacher is able to present her material in English well.

6. The teacher is using some teaching media.

7. The teacher gave a good guidance to her student to do the assignment.

8. The students were active in doing their assignment. It was supported with the facilities provided in the computer laboratory. Each student worked on a computer. It will be easier for the teacher to assess her students.

9. The students were not using English to communicate with other students and the teacher.

Findings in Syllabus Overview

1) Learning activities do not reflect what the teacher will present/ do in the classroom or how to carry out the instructional process.

2) The inconsistency in using words in stating basic competencies, the learning activities and indicators.

3) Some indicators still have more one goals that should be achieved in one activity in a single time. Every indicator should have just one goal in one activity.

4) There are still ambiguous terms. It is caused by the inappropriate diction.

5) The syllabus still does not state clearly the character building in each learning activity or in different columns.

\section{CONCLUSION}

Problems when using English as the classroom language faced by the ICT teacher of SMP Negeri 2 Semarang were as follows: 
- Vocabulary

Lack of English vocabulary resulted in too many repetitions of some words.

- Fluency

Redundant and clumsy fluency occurred as the teacher sometimes did not know how to use a certain expression in English and produced long sentences which were meaningless.

- Pronunciation

Some words happened to be mispronounced by the teacher.

- Grammar

The teacher often made grammatical errors when using some expressions.

\section{Suggestions}

1. SMP 2 Semarang needs to hold an ESP (English for Specific Program) in teaching based on findings of this article.

2. One English teacher needs to be observed how the ICT teachers conduct the teaching and learning process in the class by using English and then they discuss the results of the observation.

3. All members of SMP 2 Semarang need to use English as a second language in the school environment.

\section{REFERENCES}

Bacherman, David M. (2007). The Use of Students' First Language in Secondlanguage Learning in a Computer-based Environment. Ph.D. dissertation, Walden University, United States -- Minnesota. Retrieved on July 8, 2011, from Dissertations \& Theses: Full Text database. (Publication No. AAT 3240051).

Berliner, D. C. (1991). Educational psychology and pedagogical expertise: New findings and new opportunities for thinking about training. Educational Psychologist, 26(2), 145-155. Book, C.

Bogdan, R.C. \& Biklen, S. K. (2003). Qualitative Research for Education: An Introduction to Theory and Methods. Boston: Allyn \& Bacon. Janzen, J. 
Journal of English Education, Literature, and Culture

(Dec 2008). Teaching English Language Learners in the Content Areas. Review of Education Research. 78(4): 1010-1038.

Clegg, J.: Providing Language Support in CLIL, http://factworld.info/journal/issue06/f6-clegg.pdf. Accessed on July 8, 2011.

Herskin, B. (2004b). The IT pedagogical concept (Herskin model) (in Danish. Original title: Det IT pædagogiske koncept (Herskin-modellen)). Retrieved June 2011, from: http://www.teachtoteach.dk/upload/application/c83bc19e/itpaedagogi ske_koncept.pdf

Kennedy, M. M. and Barnes, H. (1997). Implications of cognitive science for teacher education. In J. N. Mangieri and C. C. Block (Eds). Creating Powerful thinking in teachers and students: Diverse Perspectives. New York: Holt Rinehart and Winston.

Main, J. \& Eggen, P. (1991). Developing Critical Thinking Through Science. Midwest Publications, U.S.

Pandian, A. (2001). English Language Education in Malaysia - Past, Present and Future. Literacy Matters - Issues for New Times. ed. Mary Kalantzis \& Ambigapathy Pandian, Common Ground Publishing, Australia.

Pandian, A. (2002). Literacy and Learning. Learning for the Future, ed. Mary Kalantzis, Gella Varnava-Skoura and Bill Cope, Common Ground Publishing, Australia.

Pillay, H. (1998). Issues in Teaching of English in Malaysia. The Language Teacher Online, 22.11. Retrieved from http://www.langue.hyper.chubu.ac. Accessed on July 8, 2011.

Rokeach, M. (1968) Beliefs, attitudes and values: A theory of organizational change. San Francisco: Jossey Bass.

Tong, Fuhui; Lara-Alecio, Rafael; Irby, Beverly; Mathes, Patricia \& Kwok, Oiman. (2008). Accelerating Early Academic Oral English Development in Transitional Bilingual and Structured English Immersion Programs. American Educational Research Journal, 45(4), 1011-1044. Retrieved on July 8, 2011, from ProQuest Education Journals database. (Document ID: 1607386511). 
OTHER SOURCES

http://sains.kompas.com/read/2009/06/24/17410455/Waduh.Bahasa.Inggris 600.Guru.RSBI.Ternyata.Memble.

http://mandikdasmen.kemdiknas.go.id/web/rsbipeng/5.html

http://staff.uny.ac.id/system/files/penelitian/Apri Nuryanto..

http://unnes.info/article/masalah-sekolah-berstandart-internasional 